\title{
The effect of meal frequency and protein concentration on the composition of the weight lost by obese subjects
}

\author{
BY J. S. GARROW, MERRIL DURRANT, SANDRA BLAZA, \\ DEBORAH WILKINS, P. ROYSTON AND SHIRLEY SUNKIN \\ $M R C$ Clinical Research Centre, Watford Road, Harrow, Middlesex HA13UJ
}

(Received 6 March 1980 - Accepted 10 June 1980)

1. Nitrogen balance, weight loss and resting metabolic rate were measured in thirty-eight obese inpatients on $3.4 \mathrm{MJ}(800 \mathrm{kcal}) / \mathrm{d}$ diets over 3 weeks.

2. All subjects were fed on $13 \%$ protein-energy in three meals/d for the first week.

3. In weeks 2 or 3, using a cross-over design, ten subjects were fed on 15 or $10 \%$ protein-energy as three meals $/ \mathrm{d}$; fourteen subjects were fed on five or one meal/d with $13 \%$ protein-energy; and fourteen subjects were fed on $15 \%$ protein-energy as five meals/d or $10 \%$ protein-energy as one meal/d.

4. $\mathbf{N}$ loss was least on the high-protein week and frequent-meal week: the largest difference was found when these effects were combined $(P<0.001)$.

5. When protein-energy was held constant at $13 \% \mathrm{~N}$ loss decreased significantly $(P<0.01)$ between week 2 and 3, but when the protein-energy was manipulated there was no significant $\mathbf{N}$ conservation in the third week. This suggests that the protein:energy value is more important than meal frequency in the preservation of lean tissue.

6. Weight loss was also least on the 'high-protein' week and 'frequent-meal' week, but this result reached significance only when the effects were combined $(P<0.05)$.

7. Resting metabolic rate decreased with time but was not significantly altered by the dietary regimens.

8. Therefore, during the first 3 weeks at an intake of $3.4 \mathrm{MJ} / \mathrm{d}$, a diet with a high-protein concentration, fed as frequent small meals, is associated with better preservation of lean tissue than an isoenergetic diet with lower-protein concentration fed as fewer meals. There was no evidence that meal frequency or protein concentration affect the rate of fat loss.

Cohn et al. (1963) showed that if one group of rats was fed ad lib., and a similar group of rats was force-pair-fed the identical diet in two meals/d, the force-fed rats gained more fat and excreted more nitrogen than the ad lib. control group. The higher the protein concentration in the diet, the more marked was the effect of force-feeding. This observation was linked with that of Fabry et al. (1964) who noted that there was an inverse relationship between the frequency of meals and adiposity in the population of Prague, and this has been confirmed in the Tecumseh study (Metzner et al. 1977). Mahler (1972) found that students who took a large carbohydrate supplement as a single meal gained more weight than when the supplement was divided in sixteen hourly fractions, but this result may be due to the order in which the tests were done, because the gorging protocol always preceded the nibbling one. Debry et al. (1973) compared the weight loss in 119 obese subjects who were given a reducing diet as either three or seven meals daily: the mean weight loss on seven meals/d was $142 \mathrm{~g}$, but on three meals it was only $78 \mathrm{~g} / \mathrm{d}$. All these publications may be taken as support for the view that isoenergetic diets taken as a small number of large meals (gorging) are more fattening than the same diet taken as a large number of small meals (nibbling).

From the viewpoint of energy balance it is difficult to understand why this should be so. If the diet is isoenergetic on the two regimens, and more fat is laid down in the gorging mode, it implies that less energy is expended when the food is taken in large infrequent meals, yet after the large meal the excess energy must be stored so it can be mobilized again during the long inter-meal fasting periods. With nibbling, however, there is less need to store and 
then withdraw energy, so it should be the nibbling mode which is metabolically more efficient. There is no published evidence to support this view, but many investigators have failed to find any significant effect of meal frequency on body-weight or body composition. Romsos, Belo et al. (1978) fed dogs either one meal $/ 48 \mathrm{~h}$ or four meals $/ 48 \mathrm{~h}$ for $246 \mathrm{~d}$, and found no effect of meal frequency on body-weight or composition. A similar experiment with pigs (Romsos, Miller et al. 1978) which lasted 5.5 months showed that the pigs on one meal gained $63.5 \mathrm{~kg}$, while those on four meals gained only $54.2 \mathrm{~kg}$, but the means were not significantly different. Bortz et al. (1966) found no difference in the weight loss of six obese females fed on a diet supplying $600 \mathrm{kcal}(2.4 \mathrm{MJ})$ daily in either three, one or nine meals/d. Studies on normal students approximately in energy balance on either three or six meals/d (Irwin \& Feeley, 1967), or two, three or nine meals/d (Swindells et al. 1968), or one, three or six meals/d (Young et al. 1971), or three or six meals/d (Finkelstein \& Fryer, 1971) failed to show any significant relationship between meal frequency and weight change or $\mathbf{N}$ metabolism, although several of these studies showed effects on lipid metabolism. Fabry (1976) concluded that the evidence from animal and human studies was conflicting, but that probably the effect of meal frequency on weight change was small, and could only be shown with very-well-controlled studies.

We have previously reported (Durrant et al. 1978) that obese patients given a diet supplying $3.4 \mathrm{MJ}(800 \mathrm{kcal}) / \mathrm{d}$ in a gorging regimen showed greater $\mathrm{N}$ loss than with a regimen of five meals/d. In order to provide a single meal of acceptable size for the gorging regimen, food of high energy density was used. However it was retrospectively observed that owing to the use of high-energy food the gorging regimen had a significantly lower concentration of protein than the nibbling mode. This might have explained the greater $\mathbf{N}$ loss (Durrant et al. 1980).

This paper reports the effects of differences in protein concentration and meal frequency, separately and combined, on weight loss and $\mathrm{N}$ balance in thirty-eight obese subjects.

\section{EXPERIMENTAL}

\section{Subjects}

Subjects were recruited from a hospital outpatient clinic to which they had been referred by their family practitioner. If they failed to lose weight or maintain weight within the desirable range under outpatient supervision they were offered a place in a metabolic unit where they were guaranteed to lose weight. The experimental protocol and strict supervision whilst in the unit were explained to subjects before admission and also in the presence of a senior nurse after admission. Patient consent was obtained before any tests were performed. The procedures had been approved by the Northwick Park Hospital Ethical Committee.

A total of thirty-eight subjects were used in these trials, thirty-five were female and three were male. Subjects were allocated to the trial current at the time of admission (see p. 7). Analysis of the age, weight and obesity index for subjects on the different trials revealed no discernible differences between groups (Table 1).

\section{Research unit}

The unit accommodated a maximum of three subjects in one single-bedded and one two-bedded room, and occupied the end of a research paediatric ward which is staffed by personnel trained in metabolic work. Leisure facilities were provided in a day-room. Patients were not allowed to leave the unit at any time unless accompanied by a member of staff. Visitors entered at the far end of the children's ward and were not allowed to take bags or outdoor clothing into the unit. This system ensured that patients had no access to food other than that provided from the diet kitchen. 
Table 1. Details of subjects

(Mean values and standard deviations, ranges in parentheses)

\begin{tabular}{|c|c|c|c|c|}
\hline \multirow{2}{*}{$\begin{array}{l}\text { Expt } \\
\text { No. }\end{array}$} & \multirow{2}{*}{$\begin{array}{c}\text { No. of } \\
\text { subjects }\end{array}$} & \multirow{2}{*}{$\frac{\text { Age (years) }}{\text { Mean SD }}$} & \multirow{2}{*}{$\frac{W t(k g)}{\text { Mean sD }}$} & $\begin{array}{c}\text { Obesity } \\
\text { Index } \\
\left(\mathbf{k g} / \mathbf{m}^{2}\right)\end{array}$ \\
\hline & & & & Mean SD \\
\hline 1 & 10 & $\begin{array}{c}3716 \\
(19-52)\end{array}$ & $\begin{array}{cc}99 \cdot 4 & 21 \cdot 1 \\
(78 \cdot 4-145 \cdot 3)\end{array}$ & $\begin{array}{cc}37.7 & 9.7 \\
(28.6-61.8)\end{array}$ \\
\hline 2 & 14 & $\begin{array}{cc}41 & 14 \\
(18-56)\end{array}$ & $\begin{array}{c}99 \cdot 6 \quad 13 \cdot 0 \\
(69 \cdot 7-117 \cdot 1)\end{array}$ & $\begin{array}{c}37.7 \quad 4.8 \\
(30.9-44.9)\end{array}$ \\
\hline 3 & $14^{*}$ & $\begin{array}{cc}3910 \\
(19-55)\end{array}$ & $\begin{array}{c}100 \cdot 2 \quad 25 \cdot 0 \\
(70 \cdot 3-162 \cdot 3)\end{array}$ & $\begin{array}{cc}36.7 & 6.6 \\
(27.1-51.8)\end{array}$ \\
\hline Total & 38 & 3913 & $\begin{array}{lll}99.8 & 19.7\end{array}$ & $37.3 \quad 6.8$ \\
\hline
\end{tabular}

- Including three male subjects.

\section{Food}

Food was prepared and served, and uneaten food was weighed-back by trained metabolic cooks from the diet kitchen on the paediatric ward. Patients were encouraged to eat all the food served at the specified meal times. Subjects eating less than $80 \%$ of their food allowance were excluded.

Food used in the studies was homogenous so that any food left was of the same composition as that eaten. A range of foods (e.g. milkshakes, fruit juice, soup, jelly, mousse and sandwiches with spreads) was developed. Foods were also adapted so that each type could vary in energy density over a threefold range without noticeable changes in taste or texture (Garrow et al. 1978).

The food ingredients were bought in bulk at the outset of the trials. Energy content was determined by bomb calorimetry and $\mathrm{N}$ content by Kjeldahl analysis. The results of these analyses of foods were filed on a computer program. Milk and eggs were the sources of dietary protein. Samples of food served to patients were taken at intervals and analysed in order to check that food was correctly prepared. Patients were allowed ad lib. access to energy-free fluids. They recorded fluid intake (units cups) and coffee intake on charts provided.

\section{Treatment protocols}

Admission was on Wednesdays between 10.00-16.00 hours. Patients were interviewed about their food preferences and a suitable menu devised. Day 2 began with a fast from $00.00-18.45$ hours so the evening meal allowance was adjusted to normal levels for the week.

A summary of the dietary design for each experiment is given in Table 2.

'Week 1' diet for subjects in all studies supplied $3.24 \pm 0.18 \mathrm{MJ}(774 \pm 43 \mathrm{kcals}) / \mathrm{d}$ with a protein content of $12.6 \pm 1.6 \%$ protein-energy. Food was served as three meals/d; breakfast 09.00-10.00 hours, lunch 12.45-13.45 hours, dinner 18.45-19.45 hours. Small milk allowances were served mid-morning 10.30 hours, mid-afternoon 15.30 hours and evening 22.00 hours. The first week provided a period of constant conditions so that subjects could stabilize before entering into one of the following test periods. All experiments used a crossover design in weeks 2 and 3 so. test sequence was alternated for every patient.

Expt 1. High-protein (15\% protein-energy) v. low-protein (10\% protein-energy). Ten subjects completed the high-protein $v$. low-protein study. The food in the "high-protein' week contained $3 \cdot 14 \pm 0.21 \mathrm{MJ}(751 \pm 51 \mathrm{kcals}) / \mathrm{d}$ with $14.9 \pm 0.5 \%$ protein-energy. The food in the 'low-protein' week contained $3.26 \pm 0.20 \mathrm{MJ}(778 \pm 48 \mathrm{kcals}) / \mathrm{d}$ with $10.3 \pm 0.7 \%$ protein-energy. The food was served as three meals/d with the timing identical to week 1 . 
Table 2. Dietary design of experiment

\begin{tabular}{ccccc}
\hline \hline Expt no. & Week* & $\begin{array}{c}\text { Actual energy } \\
\text { intake (MJ (kcal)/d) }\end{array}$ & $\begin{array}{c}\text { Protein } \\
\text { energy (\%) }\end{array}$ & Meals/d \\
\hline \multirow{2}{*}{1} & 1 & $3 \cdot 25(766)$ & 13 & 3 \\
& $2 \times 3$ & $3 \cdot 15(751)$ & 15 & 3 \\
& $3 \times 2$ & $3 \cdot 26(778)$ & 10 & 3 \\
& 1 & $3 \cdot 25(766)$ & 13 & 3 \\
& $2 \times 3$ & $3 \cdot 43(819)$ & 13 & 5 \\
& $3 \times 2$ & $3 \cdot 43(816)$ & 13 & 1 \\
& 1 & $3 \cdot 26(780)$ & 13 & 3 \\
& $2 \times 3$ & $3.43(819)$ & 15 & 5 \\
& $3 \times 2$ & $3.43(816)$ & 10 & 1 \\
\hline \hline
\end{tabular}

* During weeks 2 and 3 test sequence was alternated for each subject.

Expt 2. Frequent meals (five/d) v. infrequent meals (one/d). Fourteen subjects completed the meal-frequency study. The food in the 'frequent-meal' week contained $3.43 \pm 0.07 \mathrm{MJ}$ $(819 \pm 17 \mathrm{kcal}) / \mathrm{d}$ and $13 \cdot 0 \pm 0 \cdot 3 \%$ protein-energy. Meals comprising $13-25 \%$ energy intake were served five times/d at $09.00-10.00,12.45-13.45,15.00-15.30,18.45-19.45$ and 22.00-22.30 hours. The food in the infrequent meal week contained $3.41 \pm 0.05 \mathrm{MJ}$ $(816 \pm 13 \mathrm{kcal}) / \mathrm{d}$ and $13.1 \pm 0.3 \%$ protein-energy. One meal $/ \mathrm{d}$ comprising $75-80 \%$ of energy intake was served at $12.45-13.45$ hours. The remaining $20-25 \%$ of intake was distributed throughout the day to allow drinks of fruit juice or milk for tea and coffee.

Expt 3. High-protein high-frequency meals v. low-protein low-frequency meals. Fourteen subjects completed a study where high-protein diets (15\% protein-energy) were given frequently (five/d) and low-protein diets (10\% protein-energy) were given infrequently (one/d). Energy intake during the 'high-protein high-frequency' week was $3 \cdot 24 \pm 0 \cdot 23 \mathrm{MJ}$ $(774 \pm 54 \mathrm{kcal}) / \mathrm{d}$ with $15 \cdot 3 \pm 3 \cdot 3 \%$ protein-energy. Energy intake during the 'low-protein low-frequency' week was $3 \cdot 31 \pm 0 \cdot 13 \mathrm{MJ}(791 \pm 30 \mathrm{kcal}) / \mathrm{d}$ with $10 \cdot 2 \pm 2 \cdot 4 \%$ protein-energy. Meal times were identical to those in Exp 2.

\section{Measurements on patients}

The height $(\mathrm{m})$ of each patient was measured on admission to the unit. Body-weight $(\mathrm{kg})$ was measured with an accuracy of $\pm 50 \mathrm{~g}$ each weekday-using a beam balance. The balance had a variable zero so the patient was unaware of her weight change. Patients wore light cotton suits of standard weight and were weighed fasting and having voided urine. Rate of weight loss was calculated in $\mathrm{g} / \mathrm{d}$ for each treatment week. As day 1 was an incomplete day (i.e. less than $24 \mathrm{~h}$ ) and was excluded from all analyses, week 1 values given were the means of $6 \mathrm{~d}$. Week 2 and 3 values are means of $7 \mathrm{~d}$.

Obesity index (body-weight/height ${ }^{2}$ ) was calculated using body-weight on day 2.

$\mathrm{N}$ output was measured from $24 \mathrm{~h}$ daily urine and stool collections. Creatine was measured on all daily urine samples and this was used as a check for complete collections. A $1 \%$ sample of each day's output of urine was pooled for each treatment week and weekly samples analysed. Stool samples were frozen in $7 \mathrm{~d}$ batches. They were thawed, made up to a known weight with distilled water, homogenized and portions analysed. All analyses were done in duplicate by routine Kjeldahl analysis. $\mathbf{N}$ balance was derived by subtracting $\mathrm{N}$ output (urine + stool) from $\mathrm{N}$ i input (see p. 7). Skin, blood and menstrual losses were not measured. Subjects were in negative $\mathbf{N}$ balance most of the time so the results are expressed as $\mathbf{N}$ loss $(\mathrm{g} / \mathrm{d})$, averaged for each test week.

Fasting resting metabolic rate (RMR) was measured using a ventilated-hood system of 
indirectly calorimetry as previously described (Garrow \& Hawes, 1972). Measurements were made between $08.00-09.30$ hours on days 2,3 and 7 or 8 during week 1 . The mean of these three readings is used as the week 1 value. RMR was measured subsequently at the end of each test week. Mean values for each test week were derived by averaging the two values at the outset and end of each test week.

\section{RESULTS}

The effect of test, time and order of testing on $\mathbf{N}$ loss for all experiments is shown in Table 3.

The mean $( \pm \mathrm{SD})$ values for $\mathrm{N}$ loss and weight loss in all experiments are given in Table 4. The means for the weeks are presented in sequence weeks $1,2,3$ and then by test. 'Test-week' means are derived from all the values of that test regardless of whether it was week 2 or 3. Week 1 was designed as a stabilization week and was therefore not analysed. The results for weeks 2 and 3 were analysed by Student's paired $t$ test appropriate for cross-over designs (Hills \& Armitage, 1979). The $t$ values were calculated as the mean difference in values for the 2 weeks (sequence effect) and for the two diets (test effect) divided by the standard error of the mean difference. Finally the ratio, $\mathrm{N}$ loss (g): weight loss (kg) was calculated for each week.

One feature of the cross-over design, not available in the ordinary paired $t$ test, was the possibility of testing for interaction between sequence and test effects. A significant interaction implied that the test effect was not of consistent magnitude in the two cross-over periods.

\section{Expt 1. High-protein v. low-protein}

The mean ( \pm SD) $N$ loss, weight loss and $N$ : weight loss are given in Table 4. $N$ loss decreased with time from 4.34 to $1.89 \mathrm{~g} / \mathrm{d}$ but most of this adaptation occurred between weeks 1 and 2 . The sequence effect was not significant between weeks 2 and $3 . N$ loss was significantly less $(t 3.87, P<0.01)$ in the 'high-protein' week $(1.52 \mathrm{~g} / \mathrm{d})$ than the 'low-protein' week $(2.51 \mathrm{~g} / \mathrm{d})$. The diet $\times$ sequence interaction was not significant $(t 0.8, P=0.4)$.

Weight loss decreased from 326 to $192 \mathrm{~g} / \mathrm{d}$ over the 3 weeks. The adaptation in weight loss occurred mainly between weeks 1 and 2 . Weight loss was lower $(176 \mathrm{~g} / \mathrm{d})$ in the 'high-protein' week compared with $226 \mathrm{~g} / \mathrm{d}$ on the 'low-protein' diet but this difference is not statistically significant $(t 0.96, P<0.35)$.

$\mathrm{N}$ : weight loss values reinforced the trends indicated previously. The value was highest in week $1,13.3 \mathrm{~g} / \mathrm{kg}$, and fell to $10 \mathrm{~g} / \mathrm{kg}$ in weeks 2 and 3 . The value was lower for the 'high-protein' week $(8.6 \mathrm{~g} / \mathrm{kg})$ than the 'low-protein' week $(11 \cdot 1 \mathrm{~g} / \mathrm{kg})$.

Table 3. Mean weekly nitrogen loss $(g / d)$ with time, test and order of testing for all experiments

\begin{tabular}{llll}
\hline \hline & Week 1 & Week 2 & Week 3 \\
\hline Expt 1 & & & \\
$13 / 15 \times 10 \mathrm{PE}$ & 4.16 & 1.79 & 2.53 \\
$13 / 10 \times 15 \mathrm{PE}$ & 4.52 & 2.46 & 1.25 \\
Expt 2 & & & \\
$3 / 5 \times 1 \mathrm{M}$ & 3.45 & 0.68 & 0.44 \\
$3 / 1 \times 5 \mathrm{M}$ & 4.77 & 3.70 & 1.92 \\
Expt 3 & & & \\
$13,3 / 15,5 \times 10,1 \mathrm{PEM}$ & 3.25 & 0.99 & 3.00 \\
$13,3 / 10,1 \times 15,5 \mathrm{PEM}$ & 4.26 & 2.31 & 0.25 \\
\hline
\end{tabular}


J. S. GARROW AND OTHERS

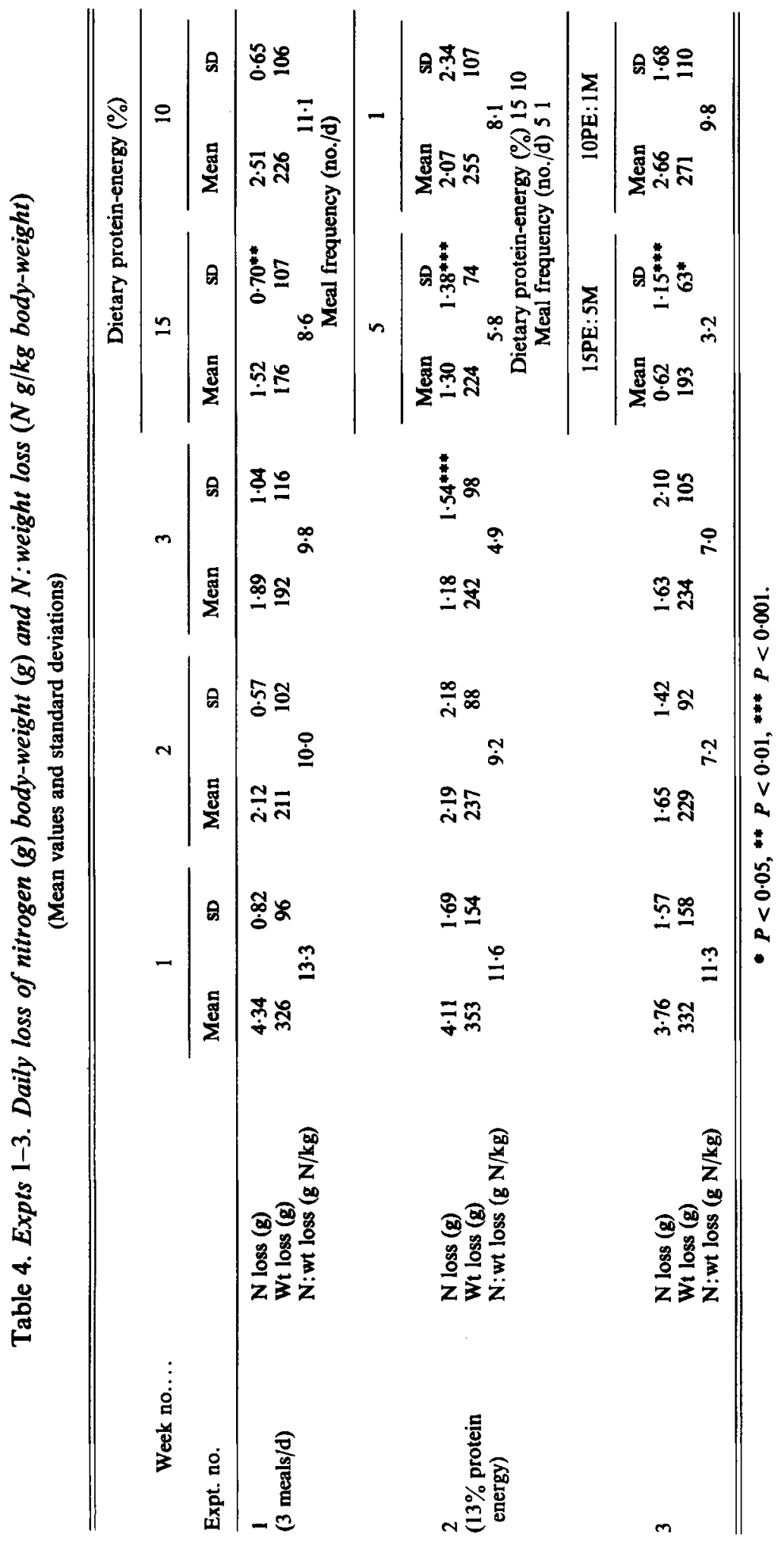


Mean ( \pm SD) RMR (ml oxygen/min) was $250 \pm 53$ in week $1,236 \pm 43$ in week 2 and $228 \pm 36$ in week 3 . Apart from the initial drop between weeks 1 and 2 there was no significant effect of time or diet.

\section{Expt 2. High meal frequency $\mathrm{v}$. low meal frequency}

The mean ( $\pm \mathrm{SD})$ loss for $\mathrm{N}$, weight loss and $\mathrm{N}$ : weight loss are given in Table 4. $\mathrm{N}$ loss $(\mathrm{g} / \mathrm{d})$ decreased with time from 4.11 in week 1 to 2.19 in week 2 and 1.18 in week 3 . There was a large drop between weeks $1-2$ and weeks $2-3$ the latter being significant $(t 5.67$, $P<0.001)$. N loss was significantly less $(t 4.40, P<0.001)$ in the 'frequent-meal' week $(1.30 \mathrm{~g} / \mathrm{d})$ than in the 'infrequent-meal' week $(2.07 \mathrm{~g} / \mathrm{d})$.

However, there was also a significant diet $\times$ sequence interaction $(t 2.91, P<0.02)$. This indicated that the diet had produced different $\mathrm{N}$ balance changes in week $2(3.03 \mathrm{~g})$ compared with week $3(1.47 \mathrm{~g})$. Even so, the nibbling diet still produced a significant between-subject (as opposed to within-subject) reduction in $N$ loss in week $2(t 3.60$, $P<0.005)$ and a near-significant reduction in week $3(t 1.99, P=0.07)$, compared with the gorging diet.

Weight loss decreased from 353 to approximately $240 \mathrm{~g} / \mathrm{d}$ in weeks 2 and 3 with no difference in the latter weeks. Weight loss was lower in the frequent meal week $(224 \mathrm{~g} / \mathrm{d})$ than in the infrequent meal week $(255 \mathrm{~g} / \mathrm{d})$ but this difference was not statistically significant.

$\mathrm{N}$ : weight loss was highest in week $1(11.6 \mathrm{~g} / \mathrm{kg})$ and decreased with time to $4.9 \mathrm{~g} / \mathrm{kg}$ in week 3 . The value was lower for the 'frequent-meal' week $(5 \cdot 8 \mathrm{~g} / \mathrm{kg})$ than for the 'infrequentmeal' week $(8 \cdot 1 \mathrm{~g} / \mathrm{kg})$.

Mean ( \pm SD) RMR $\left(\mathrm{ml} \mathrm{O}_{2} / \mathrm{min}\right)$ was $272 \pm 34$ in week $1,262 \pm 32$ in week 2 and $258 \pm 29$ in week 3. There was no significant change in RMR with time or diet.

\section{Expt 3. High-protein high-frequency v. low-protein low-frequency}

The mean $( \pm \mathrm{SD}) \mathrm{N}$ loss, weight loss and $\mathrm{N}$ : weight loss are given in Table $4 . \mathrm{N}$ loss decreased from 3.76 to $1.64 \mathrm{~g} / \mathrm{d}$ in weeks 2 and 3 . N loss was highly significantly less $(t 5.96, P<0.001)$ in the 'high-protein high-frequency' week ( $0.62 \mathrm{~g} / \mathrm{d})$ than in the 'low-protein low-frequency' week $(2.66 \mathrm{~g} / \mathrm{d})$. The diet $\times$ sequence interaction was not significant $(t 1 \cdot 0, P=0.3)$.

Weight loss decreased from 332 to approximately $230 \mathrm{~g} / \mathrm{d}$ in weeks 2 and 3 . Weight loss was significantly lower $(t 2.23, P<0.05)$ in the 'high-protein high-frequency' week $193 \mathrm{~g} / \mathrm{d}$ than in the 'low-protein low-frequency' week $271 \mathrm{~g} / \mathrm{d}$.

$\mathrm{N}$ : weight loss ratios were highest in week $1(11.3 \mathrm{~g} / \mathrm{kg})$ and decreased to approximately $7.0 \mathrm{~g} / \mathrm{kg}$ in the second and third weeks. The value was lowest in the 'high-protein high-frequency' week $(3.2 \mathrm{~g} / \mathrm{kg})$ and highest in the 'low-protein low-frequency' week $(9 \cdot 8 \mathrm{~g} / \mathrm{kg})$.

Mean ( $\pm \mathrm{SD}) \mathrm{RMR}(\mathrm{ml} \mathrm{O} / \mathrm{min})$ was $272 \pm 48$ in week $1,246 \pm 43$ in week 2 and $243 \pm 40$ in week 3 . Apart from the initial drop between weeks 1 and 2 there was no significant effect of time or diet.

The effect of meal frequency and protein concentration on weight loss and body composition are illustrated in Figs. 1 and 2. Only the results from weeks 2 and 3 have been used. Week 1 provided a period of stabilization, on three meals with $13 \%$ protein-energy. The effect on weight loss is shown in Fig 1 . When protein concentration was held constant at $13 \%$ protein-energy there was slightly more weight loss with one meal/d than with five/d $(255$ v. $224 \mathrm{~g} / \mathrm{d})$. If meal frequency was held constant at three meals/d but the protein concentration was altered there was greater weight loss on $10 \%$ protein-energy than on $15 \%$ protein-energy $(226 v .176 \mathrm{~g} / \mathrm{d})$. If both were altered together the effects were additive, so one meal of $10 \%$ protein-energy gave significantly more weight loss $(P<0.05)$ than five meals of $15 \%$ protein-energy ( 271 v. $193 \mathrm{~g} / \mathrm{d})$. 


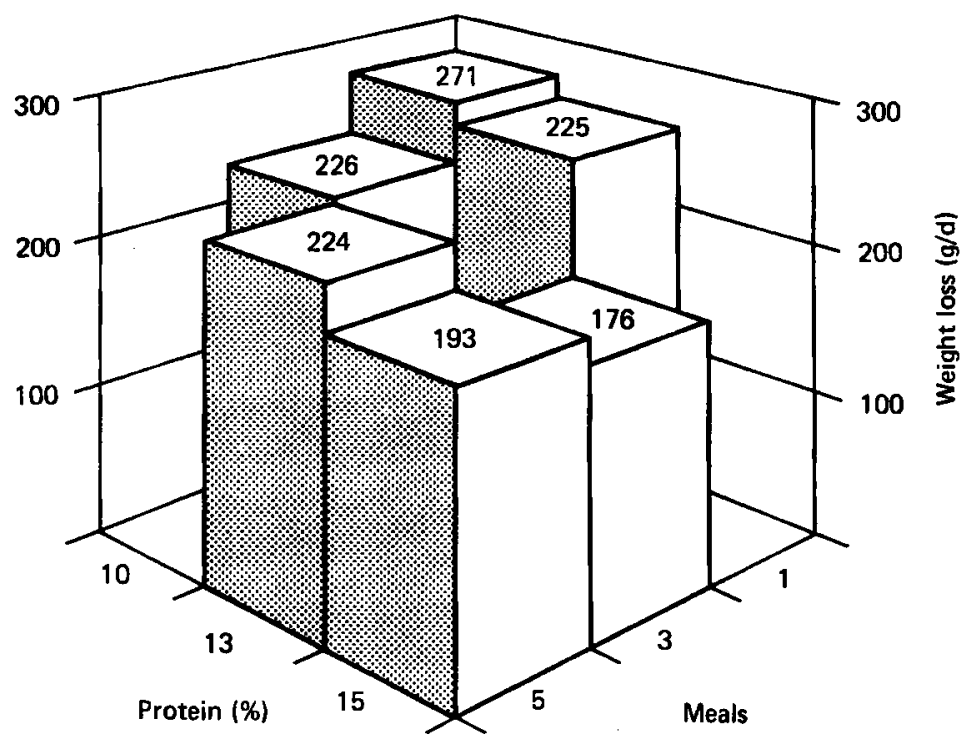

Fig. 1. Average daily weight loss (g/d) during the second or third week of dieting among thirty-eight obese patients who were given $3.4 \mathrm{MJ} / \mathrm{d}$ in three meals/d with $13 \%$ protein-energy for the first week, and then either one or five meals/d with either 10 or $15 \%$ protein-energy in a cross-over design for the subsequent 2 weeks.

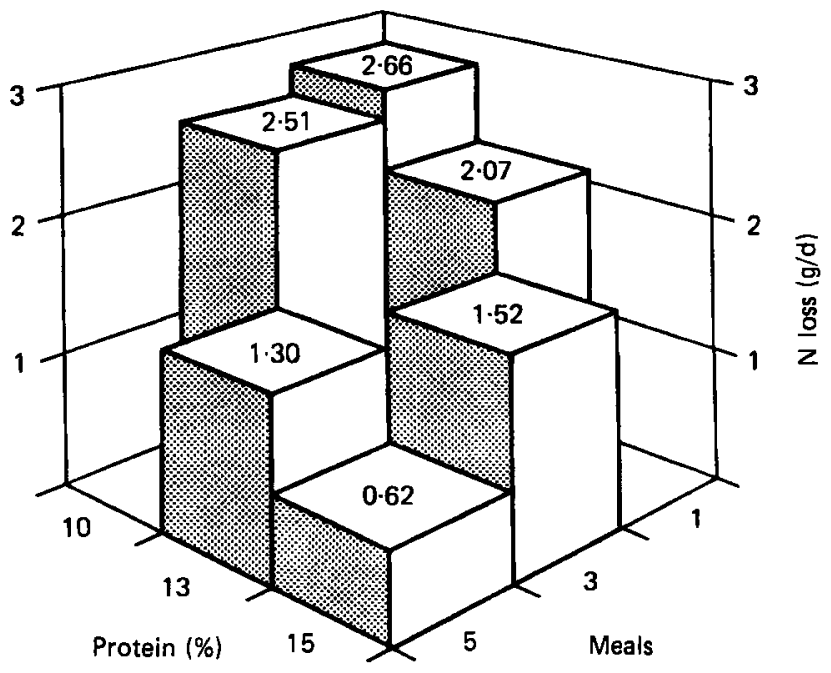

Fig. 2. Average daily negative $N$ balance $(g / d)$ for thirty-eight obese patients who were given $3.4 \mathrm{MJ} / \mathrm{d}$ in three meals/d with $13 \%$ protein-energy for the first week, and then either one or five meals/d with either 10 or $15 \%$ protein-energy in a cross-over design for the subsequent 2 weeks. 
Table 5. Composition of weight loss in weeks 2 and 3

\begin{tabular}{|c|c|c|c|c|c|}
\hline Expt No. & Meals/d & $\begin{array}{c}\text { Protein } \\
\text { energy }(\%)\end{array}$ & $\begin{array}{l}\text { Weight loss } \\
(\mathrm{g} / \mathrm{d})\end{array}$ & $\begin{array}{c}N \text { loss } \\
(\mathrm{g} / \mathrm{d})\end{array}$ & $\begin{array}{l}\text { Fat loss } \\
(\mathrm{g} / \mathrm{d})\end{array}$ \\
\hline 1 & $\begin{array}{l}3 \\
3\end{array}$ & $\begin{array}{l}15 \\
10\end{array}$ & $\begin{array}{l}176 \\
226\end{array}$ & $\begin{array}{l}1.52 \\
2.51\end{array}$ & $\begin{array}{l}126 \\
143 .\end{array}$ \\
\hline 2 & $\begin{array}{l}5 \\
1\end{array}$ & $\begin{array}{l}13 \\
13\end{array}$ & $\begin{array}{l}224 \\
255\end{array}$ & $\begin{array}{l}1.30 \\
2.07\end{array}$ & $\begin{array}{l}181 \\
187\end{array}$ \\
\hline 3 & $\begin{array}{l}5 \\
1\end{array}$ & $\begin{array}{l}15 \\
10\end{array}$ & $\begin{array}{l}192 \\
271\end{array}$ & $\begin{array}{l}0.62 \\
2.66\end{array}$ & $\begin{array}{l}172 \\
183\end{array}$ \\
\hline
\end{tabular}

Fig. 2 shows a similar, but more pronounced effect on $\mathrm{N}$ loss: in each instance the difference was significant. $\mathrm{N}$ loss was greater on three meals of $10 \%$ protein-energy than on $15 \%$ protein-energy $(2.51 v .1 .52 \mathrm{~g} / \mathrm{d}, P<0.01)$, it was greater on one meal than five meals of $13 \%$ protein-energy $(2.07 v .1 .30 \mathrm{~g} / \mathrm{d} ; P<0.001)$, and the effects were additive when both were altered $(2.66 v .0 .62 \mathrm{~g} / \mathrm{d} ; P<0.001)$.

We have previously shown that there is good agreement between estimates of fat loss based on measurement of energy balance, $\mathrm{N}$ balance and various methods for measuring body fat (Garrow et al. 1979) if the assumption is made that weight loss is composed of loss of fat, and of lean tissue with $3 \mathrm{~g} \mathrm{~N} / \mathrm{kg}$.

Table 5 shows this calculation applied to the weight loss observed in the three experiments. It should be noted, however, that this calculation probably overestimates fat loss and underestimates lean tissue loss, since $\mathrm{N}$ loss from the skin was not measured. If $\mathrm{N}$ losses have been underestimated by $1 \mathrm{~g} / \mathrm{d}$ the estimated fat loss should be decreased by $33 \mathrm{~g} / \mathrm{d}$.

\section{DISCUSSION}

The observation that semistarved subjects show improving $\mathbf{N}$ conservation with time was made by Benedict et al. (1919) and has been confirmed many times. Thus the rate of $\mathrm{N}$ loss observed in the first week of dietary restriction does not predict subsequent $\mathbf{N}$ loss, but it is still of importance. If $\mathrm{N}$ equilibrium is reached by the sixth week (deHaven et al. 1980) the total loss of lean tissue is determined by that lost in the first weeks.

In all experiments both $\mathrm{N}$ loss and weight loss decreased between week 1 and 2. In Expt 2 the decrease in $\mathbf{N}$ loss continued between weeks 2 and 3 . However this effect of time did not occur in Expts 1 and 3. Some of the disparity between our findings and those reviewed previously (p. 5) may be explained by the effects of time. The subjects studied by Mahler (1972) always gorged first and nibbled after, and this may explain the differences in weight gain observed on the two regimens. It is impossible to reconcile our findings with those of Debry et al. (1973). They observed a greater weight loss in subjects eating frequent meals after a period on an isoenergetic diet with fewer meals/d. On the basis of our experience we would expect the second period, and the more frequent meals, to be associated with a smaller loss of both $\mathbf{N}$ and body-weight.

The results on the effects of meal frequency (Figs. 1 and 2) are in line with those of Cohn et al. (1963), who showed that rats can use a certain amount of dietary protein at a time for protein synthesis. If this rate is exceeded the dietary protein will be deaminated, the $\mathrm{N}$ will appear in the urine as urea, and the carbon skeleton of the amino acid will either be burned to release energy or be stored, ultimately as fat. There is no major conflict between our results and those of the many authors who failed to show an effect of meal frequency on weight loss: in our own series the manipulation of meal frequency alone did not give 
a significant effect on weight loss, although the trend to greater weight loss with the gorging mode is supported by the significant effects observed in $\mathrm{N}$ balance. Again, the outstanding conflict is with the results of Debry et al. (1973).

The results concerning the effect of protein concentration on $\mathrm{N}$ balance are in line with our previous finding (Durrant $e t$ al. 1980) that higher protein concentrations are more protein-sparing, even at low energy intakes. This conclusion is contrary to the findings of Calloway \& Spector (1954) who reviewed the literature on $\mathrm{N}$ balance in young active men and concluded that on an intake of $4.2 \mathrm{MJ} / \mathrm{d}$ an intake of $3 \mathrm{~g} \mathrm{~N}$ (i.e. approximately $8 \%$ protein-energy) was as $\mathrm{N}$-sparing as any higher protein intake. However, we have found a significant $(P<0.01)$ improvement in $\mathbf{N}$ balance when making such small changes as $10-15 \%$ protein-energy at an energy intake of only $3.4 \mathrm{MJ} / \mathrm{d}$.

Finally we must consider the relative effects of the diets on the metabolic rate and body composition of these obese patients. There were no measurable effects on metabolic rate apart from the well-documented decrease with time of a low-energy diet. Our results cannot sustain the view that the nibbling mode enhances energy expenditure and hence leads to greater fat loss, or conversely that the gorging mode is particularly fattening. This conclusion can be checked by making a calculation of the composition of the weight lost on the different dietary regimens (Table 5).

The practical application of this work is to indicate the best diet for an obese person who is able to tolerate an intake of only $3.4 \mathrm{MJ} / \mathrm{d}$. The gorging mode has nothing to commend it apart from a more rapid rate of weight loss, but even this is not an advantage, since the extra weight loss is lean tissue, not fat. Seaton \& Duncan (1964) reported that a regimen of two meals/d, each of $2 \mathrm{MJ}$, was an 'acceptable form of dieting for obese patients', but our own experience is that patients who are kept rigidly to a diet supplying only 3.4 MJ/d find it more tolerable if it is distributed in many small meals than if it is given as a single meal followed by a long period of fasting (Durrant et al. 1978).

Our results in this study, as in a previous report (Durrant et al. 1980) show that a high concentration of protein in the diet has a significant $\mathrm{N}$-sparing effect. Since in the long-run weight loss relates to metabolic rate, and metabolic rate to lean body mass (Garrow et al. 1978; Halliday et al. 1979) it is desirable to try to conserve lean tissue during weight loss. However, it is necessary to make two reservations about the applicability of the results given in this paper to the treatment of obese outpatients. First, our patients were in a closed metabolic ward with no access to food other than that prescribed for the experimental protocol, and what is 'acceptable' in such circumstances may not be acceptable to the outpatient going to work and subject to the food stimuli of ordinary life.

Second, our results relate to weight loss and $\mathbf{N}$ balance in the second and third week of a controlled diet, and we know that, had the study been extended over a longer period, the absolute values for both rate of weight loss and $\mathrm{N}$ loss would have changed. In Expt 1 the effect of dietary protein concentration on $\mathbf{N}$ balance was consistent between the second and third weeks, as shown by the non-significant $t$ value for diet $\times$ sequence interaction $(t 0.8, P=0.4)$. However in Expt 2 the effect of changing meal frequency on $\mathrm{N}$ balance was significantly less in the third than in the second week (interaction $t 2.91, P<0.02$ ); i.e. the $\mathrm{N}$-sparing advantage of nibbling over gorging decreased with time. In the combined trial (Expt 3) diet $\times$ sequence interaction was not significant $(t \cdot 0, P=0 \cdot 3)$, but it was slightly more pronounced than in Expt 1.

\section{REFERENCES}

Benedict, F. G., Miles, W. R., Roth, P., \& Smith, H. M. (1919). Carnegie Inst. Washington, Publ. No. 280. Bortz, W. M., Wroldsen, A., Issekutz, B. \& Rodahl, K. (1966). New Eng. J. Med. 274, 376.

Calloway, D. H. \& Spector, H. (1954). Am. J. clin. Nutr. 2, 405. 
Cohn, C., Joseph, D., Bell, L. \& Oler, A. (1963). Am. J. Physiol. 205, 71.

Debry, G., Rohr, R., Azouaou, R., Vassilitch, I. \& Mottaz, G. (1973). In Energy Balance in Man, p. 305 [M. Apfelbaum, editor]. Paris: Masson.

deHaven, J., Sherwin, R., Hendler, R., \& Felig, P. (1980). New Eng. J. Med. 302, 477.

Durrant, M. L., Garrow, J. S., Royston, P., Stalley, S. F., Sunkin, S. \& Warwick, P. M. (1980). Br. J. Nutr. 44, 275.

Durrant, M. L., Stalley, S. F., Warwick, P. M. \& Garrow, J. S. (1978). Clin. Sci. 54, 4P

Fabry, P. (1976). In Energy Balance in Man, p. 297 [M. Apfelbaum, editor]. Paris: Masson.

Fabry, P., Fodor, J., Hejl, Z., Braun, T. \& Zvolankova, K. (1964). Lancet ii, 614.

Finkelstein, B. \& Fryer, B. A. (1971). Am. J. clin. Nutr. 24, 465.

Garrow, J. S., Durrant, M. L., Mann, S., Stalley, S. F. \& Warwick, P. (1978). Int. J. Obesity 2, 441.

Garrow, J. S. \& Hawes, S. F. (1972). Br. J. Nutr. 27, 211.

Garrow, J. S., Stalley, S., Diethelm, R., Pittet, Ph., Hesp, R. \& Halliday, D. (1979). Br. J. Nutr. $42,173$.

Halliday, D., Hesp, R., Stalley, S. F., Warwick, P., Altman, D. G. \& Garrow, J. S. (1979). Int. J. Obesity, 3, 1.

Hills, M. \& Armitage, P. (1979). Br. J. Pharmac. 8, 7.

Irwin, M. I. \& Feeley, R. M. (1967). Am. J. clin. Nutr. 20, 816.

Mahler, R. (1972). Acta diabet. latina 9, 449 suppl. 1.

Metzner, H. L., Lamphiear, D. E., Wheeler, N. C. \& Larkin, F. A. (1977). Am. J. clin. Nutr. $30,712$.

Romsos, D. R., Belo, P. S., Bergen, W. G. \& Leveille, G. A. (1978). J. Nutr. 108, 238.

Romsos, D. R., Miller, E. R. \& Leveille, G. A. (1978). Proc. Soc. Exptl Biol. Med. 157, 528.

Seaton, D. A. \& Duncan, L. J. P. (1964). Lancet ii, 612.

Swindells, Y. E., Holmes, S. A. \& Robinson, M. F. (1968). Br. J. Nutr. 22, 667.

Young, C. M., Scanlan, S. S., Topping, C. M., Simko, V. \& Lutwak, L. (1971). J. Am. Diet. Ass. 59, 466. 